\title{
Examining the Relationship between Drought Indices and Groundwater Levels
}

\author{
Navaratnam Leelaruban ${ }^{1}$, G. Padmanabhan ${ }^{1}$ and Peter Oduor ${ }^{2, *}$ \\ 1 Department of Civil and Environmental Engineering, North Dakota State University, Fargo, ND 58108, USA; \\ N.Leelaruban@ndsu.edu (N.L.); G.Padmanabhan@ndsu.edu (G.P.) \\ 2 Department of Geosciences, North Dakota State University, Fargo, ND 58108, USA \\ * Correspondence: Peter.Oduor@ndsu.edu; Tel.: +1-701-231-7145
}

Academic Editor: Athanasios Loukas

Received: 1 October 2016; Accepted: 19 January 2017; Published: 27 January 2017

\begin{abstract}
Thorough characterization of the response of finite water resources to climatic factors is essential for water monitoring and management. In this study, groundwater level data from U.S. Geological Survey Ground-Water Climate Response Network wells were used to analyze the relationship between selected drought indices and groundwater level fluctuation. The drought episodes included in this study were selected using climate division level drought indices. Indices included the Palmer Drought Severity Index, Palmer Hydrological Drought Index, and Standardized Precipitation Index (SPI-6, 9, 12, 24). Precipitation and the average temperature were also used. SPI-24 was found to correlate best with groundwater levels during drought. For 17 out of 32 wells, SPI-24 showed the best correlation amongst all of the indices. For 12 out of 32 wells, SPI-24 showed correlation coefficients of -0.6 or stronger; and for other wells, reasonably good correlation was demonstrated. The statistical significance of SPI-24 in predicting groundwater level was also tested. The correlation of average monthly groundwater levels with SPI-24 does not change much throughout the timeframe, for all of the studied wells. The duration of drought also had a significant correlation with the decline of groundwater levels. This study illustrates how drought indices can be used for a rapid assessment of drought impact on groundwater level.
\end{abstract}

Keywords: groundwater; drought; SPI; correlation; aquifers

\section{Introduction}

This paper reports the results [1] of a substantially expanded version of a preliminary study on the correlation between groundwater levels and drought indices, published in the 2015 Proceedings of World Environmental and Water Resources Congress. The main difference is that in this study, we are establishing a parametric linkage between groundwater level fluctuations and drought; a vital element for water monitoring and management. In most areas, groundwater is used either as a sole source, or as an alternative water source during drought events. Groundwater and drought have inherent complexities, yet are relatively concomitant. Although drought is contextual, without a universally accepted definition [2], its central theme is related to a period of water deficiency in relation to demand. Since it is inherently difficult to identify or predict a drought's onset and offset, indices are predominantly used [3-5]. These indices are utilized to identify and monitor drought [6]. The four types of drought which are generally recognized include: (i) meteorological; (ii) agricultural; (iii) hydrological; and (iv) socio-economic drought [2,7]. The first two types, that is, meteorological and agricultural droughts, are defined on the basis of precipitation and soil moisture deficits, respectively [2,7]. On the other hand, hydrological drought is applicable to shortfalls of surface/subsurface water supply, whereas socioeconomic drought is associated with the supply and demand of some economic good [2,7]. Mishra and Singh [8] suggested that groundwater deficit 
should be classified as a type of drought, in addition to the aforementioned four types. Groundwater drought can only be defined in terms of groundwater level decline, due to difficulties of quantifying groundwater storage, recharge, aquifer type, and areal extents [9,10]. Loon [11] explained hydrological drought in detail. In the study, associated challenges were listed in hydrological drought studies, including: (a) the difficulty of quantifying drought impact; and (b) the lag of water system responses to drought.

Various authors emphasize the need to evaluate the relationship of stream flow and groundwater, with meteorological variables-based drought indices [12-21]. The relationship between stream flow and drought indices has been studied by several authors. For example, Haslinger et al. [18] established a methodology for directly relating various meteorological drought indices and stream flow data for gauging stations in northern Austria. These indices included: (i) Standardized Precipitation Index (SPI); (ii) Standardized Precipitation Evapotranspiration Index (SPEI); (iii) Palmer's Z-Index; and (iv) self-calibrating Palmer Drought Severity Index (scPDSI). Vasiliades and Loukas [19] used Palmer drought indices to ascertain hydrological drought, using simulated river discharges and soil moisture for riverine systems in Thessaly, Greece. Vicente-Serrano et al. [20] extensively studied the correlation between select drought indices and stream flow data from 151 basins worldwide. Lorenzo-Lacruz et al. [21] evaluated the ability of SPI and SPEI drought indices to correlate river discharge, investigate reservoir storage, and determine reservoir release. The knowledge base of studies linking drought and groundwater levels is limited, although Mall et al. [17] emphasized the need to study the impact of climate change and drought on groundwater resources in more depth. Most studies have used precipitation and temperature to study the relationship between drought and groundwater levels. For example, Panda et al. [15] reported the relationship between monsoon rainfall and groundwater fluctuation. Tirogo et al. [16] reported the groundwater response to rainfall for a study area in Burkina Faso, West Africa. The relationship between groundwater level fluctuation and rainfall was also studied for a selected well in Central Taiwan, by Jan et al. [14]. Chen et al. [13] found that groundwater levels greatly depended on precipitation and annual mean temperature, with a delayed response time. An empirical model developed by Chen et al. [12] linked annual precipitation and average temperature to groundwater levels, based on water budget and groundwater flow. Shahid and Hazarika [22] studied the relationship between groundwater level and rainfall for Northwestern Districts of Bangladesh, and related the groundwater drought to meteorological droughts using SPI. Fiorillo and Guadagno [23] also studied the relationship between groundwater drought and meteorological drought using SPI. However, the relationship between drought indices and groundwater level fluctuation has not been significantly explored in the past.

Our study differs from the aforementioned studies, since we have focused on groundwater response to drought by deriving a parametric relationship between drought indices and empirical groundwater levels. We conducted an event-by-event analysis to capture the specific behavior of groundwater level fluctuation during individual drought episodes. Some studies have utilized a different approach. Bloomfield and Marchant [24] developed a Standardized Groundwater level Index (SGI), incorporating a similar approach to SPI using groundwater level data from select wells in the United Kingdom. Mendicino et al. [25] proposed a Groundwater Resource Index (GRI) for drought monitoring and forecasting. This was based on a simple water balance model approach. Li and Rodell [26] empirically derived a groundwater drought index (GWI), based on Catchment Land Surface Model (CLSM) output. Li and Rodell [26] found a strong regional correlation between CLSMbased [27] GWI and in situ data-based GWI, and both GWIs displayed a higher correlation with SPI-12 and SPI-24. However, CLSM requires a substantial modeling effort. Sanchez et al. [28] proposed a standardized anomaly index, using different variables to represent different drought types. They used groundwater and stream flow to represent hydrological drought. Sawada et al. [29] developed an eco-hydrological model to identify different types of drought, and studied the mechanism of drought progress. Other studies have used remote sensing techniques to quantify declines in groundwater storage [30-33]. Most of these studies used precipitation and temperature as indicators of drought. 
Groundwater systems are influenced by many factors, including the hydrological properties of the recharge area, the hydraulic properties of aquifer, and climatic variables. Therefore, deterministic approaches for quantifying groundwater level dynamics require aquifer properties, and recharge rates, amongst other factors. Due to the limitations of such data, deterministic approaches may be difficult to implement [12], which leaves statistical analysis as a viable alternative. Whittemore et al. [34] assessed the water-level changes using climatic indices for areas affected by pumping in the High Plains Aquifer system in central United States (Kansas), and predicted the water-level changes during extended drought. They used the mean annual water-level changes from five groundwater management districts, and climatic indices such as PDSI, Palmer Z index, and SPI. They also emphasized the need for simple correlation-based approaches for the rapid assessment of groundwater responses to external forces.

In this study, groundwater level data from the U.S. Geological Survey Ground-Water Climate Response Network (USGS CRN) wells were used. Wells in this network have the least anthropogenic-induced disturbances [35]. A total of eight indices were tested and a correlation matrix was developed between groundwater levels and drought indices to evaluate the capability of indices to elucidate dynamics of groundwater level fluctuations. Linear regression models were also developed for each well, to examine the relationship between drought and groundwater level. The statistical significance of a drought index for predicting groundwater level was also tested. The seasonal variability of the groundwater level, and its relationship with drought, was also studied for selected wells. The duration of drought events and lag times of groundwater responses, with respect to the onset and termination of drought events, were also studied.

\section{Study Area and Methods}

\subsection{Study Area and Groundwater Levels Data}

The study area and the selected well locations are shown in Figure 1. Criteria for the selection of CRN wells included: (a) located in unconfined aquifers or near-surface confined aquifers; (b) had minimal artificial influences (e.g., pumping, irrigation, canals, and artificial recharge); and (c) had never gone dry [35]. This study directly used the data from CRN wells, and we did not verify whether all of the criteria were met for each well. A total of 32 USGS CRN wells (Table A1) from the Great Plains States of the United States were analyzed (Figure 1). Wyoming (WY) did not have a CRN well when this study was conducted. The beginning of the time span of groundwater level data was chosen based on the beginning of consistently available groundwater level records (Table A2). December 2013 was chosen as the end of the time span. It should be noted that the USGS revises the CRN wells from time to time and alters the listing of wells. The USGS may add additional wells to the CRN network or remove some well data, if it finds that the wells no longer meet the criteria to be included in the CRN well network. For example, USGS removed the wells KS1, KS2, NE3, SD1, SD2, and TX2; and added a well in KS and another in WY. This study used the archived data from USGS CRN wells as listed, selecting those which met the criteria to be included in the CRN database.

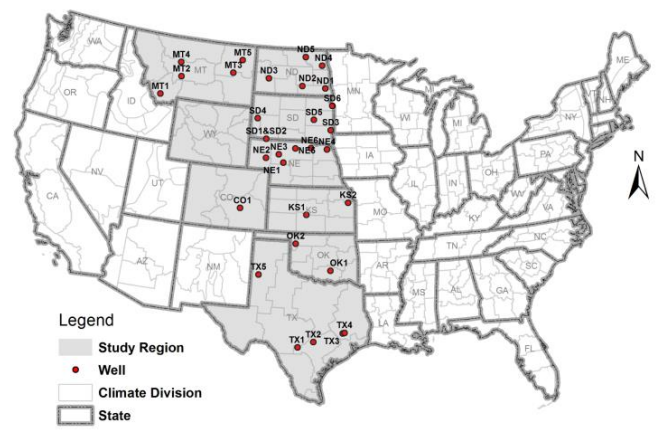

Figure 1. Study area showing selected wells' locations. 


\subsection{Drought Indices}

The Palmer Drought Severity Index (PDSI) [36]), Palmer Hydrological Drought Index (PHDI) [37], Standardized Precipitation Index (SPI) [5,38], and meteorological parameters such as Precipitation (symbolized as PCP) and Average Temperature (TMP), were used in this study. The monthly values of the PDSI, PHDI, SPI, TMP, and PCP were derived from the National Oceanic and Atmospheric Administration's (NOAA) National Climatic Data Center (NCDC) (Currently part of NOAA's National Centers for Environmental Information (NCEI)). The NCDC maintains historic data from 1895 to the present, in climatic division scale. NOAA's Gridded Climate Divisional Dataset (nCLIMDIV formerly known as Traditional Climate Division Dataset (TCDD) data) from NOAA NCDC were also used in this study. nCLIMDIV replaced the previous Traditional Climate Division Dataset (TCDD) in March 2014. The detailed description and major impacts of this transition can be found in Fenimore et al. [39]. Vose et al. [40] discussed the improvement in the nCLIMDIV data and suggested that this can be used in applied research and climatic monitoring.

The linear relationship between the monthly median depth to the water level from the land surface, $b$, and the corresponding monthly values of the PCP, TMP, PDSI, PHDI, SPI-6, SPI-9, SPI-12, and SPI-24 indices, was analyzed using the Pearson correlation coefficient. The SPI can be calculated for multiple timescales, indicating the impact on different water sectors. In this study, a SPI with a timescale of at least six months was used since it was suitable for analyzing hydrological drought impact, such as groundwater decline [41]. The drought indices used for each well were for the respective climatic division in which the well was located. In the US, each state encompasses groups of climatic divisions. The NOAA's NCDC compiles the climatic variable data at a climatic division scale (also see [42,43]).

Linear regression models were also developed for each well, to examine the relationship between SPI-24 and $b$. The rationale for focusing on SPI-24 is its inherent concomitancy with groundwater levels. The linear relationship between SPI-24 and $b$ is expressed by the equation, $b=\beta_{0}+\beta_{1}$ (SPI-24), where $\beta_{0}$ and $\beta_{1}$ are the coefficients. The coefficients were tested for statistical significance at the $5 \%$ level.

The monthly variations of groundwater levels, and correlations between SPI-24 with $b$, were studied for select wells. A subset of wells which had at least 25-year records of monthly groundwater level data, was demarcated from the rest of the dataset. This was done to identify the seasonal variability of the groundwater level and its relation to drought.

For each well, the duration in number of months under moderate or more severe drought conditions were derived, based on SPI-24. Drought is reported as moderate or more severe when SPI-24 $\leq-0.8$, using NOAA's NCEI. Therefore, the drought events for each well were delineated based on SPI-24 $\leq-0.8$, for at least 30 consecutive months. Corresponding groundwater $b$ values were also noted. From this data, groundwater level decline, and the lag and recovery time of the groundwater level in relation to the selected drought events, were determined.

\section{Results and Discussion}

The Pearson correlation coefficients between $b$ and climatic indices such as PCP, TMP, PDSI, PHDI, and SPI, for 6, 9, 12, and 24 month scales, are shown in Figure 2. The results show that precipitation and temperature have a relatively low correlation with the groundwater level. A total of 29 out of 32 wells show $r$ in the range of -0.3 to 0.21 . The highest correlation of $b$ and precipitation $(-0.51)$ is observed for well OK2. The $r$ values of $b$ and the temperature vary between -0.23 and 0.19 . Precipitation, by and large, correlates negatively, as expected. Temperature, on the other hand, shows a positive and negative correlation with $b$.

Since $b$ correlates negatively with drought indices; the more negative the index value (the more severe the drought), the greater the depth to the groundwater. The PHDI and SPI-24 displayed better correlations with groundwater levels, albeit inconsistently (Figure 2). A total of 12 out of 32 wells show an $r$ value of -0.6 or better with SPI-24; 9 wells show an $r$ of -0.6 or better with PHDI. A detailed description of $r$ with indices follows: NE4 and NE5 displayed an $r$ value of -0.9 and -0.8 , for SPI- 24 . For (i) wells KS2 and MT5 with respect to SPI-24; (ii) OK1 with respect to PHDI; (iii) OK2 with respect 
to PDSI; and (iv) TX2 with respect to SPI-9, the $r$ value was $-0.8 \leq r \leq-0.7$. For wells KS1, MT2, ND5, NE2, SD3, and SD4 with SPI-24, the $r$ value was $-0.7 \leq r \leq-0.6$, similar to wells ND1 and ND3 with respect to PHDI. The correlation values for wells MT1 and SD6 considering SPI-24; and for CO1 with respect to SPI-9, were $-0.6 \leq r \leq-0.5$. Four wells (ND4, SD5 and TX4 with SPI-24; and MT3 with SPI-12) had correlation values that ranged between -0.5 and -0.4 ; one well (ND2 with SPI-24) with a correlation value of -0.32 ; four wells (TX3 with SPI-24; NE3 and SD2 with PHDI; and TX1 with SPI-12) had correlation values between -0.3 and -0.2 ; and one well (NE6 with SPI-24) had a correlation value of -0.05 . Wells MT4, NE1, SD1, and TX5 displayed positive correlation values with respect to drought indices. Some factors that can possibly be attributed to the inconsistent correlation may be due to different hydrostratigraphic and hydrological conditions at each well. However, we can still unequivocally state that the results show that drought indices are helpful in monitoring groundwater levels.

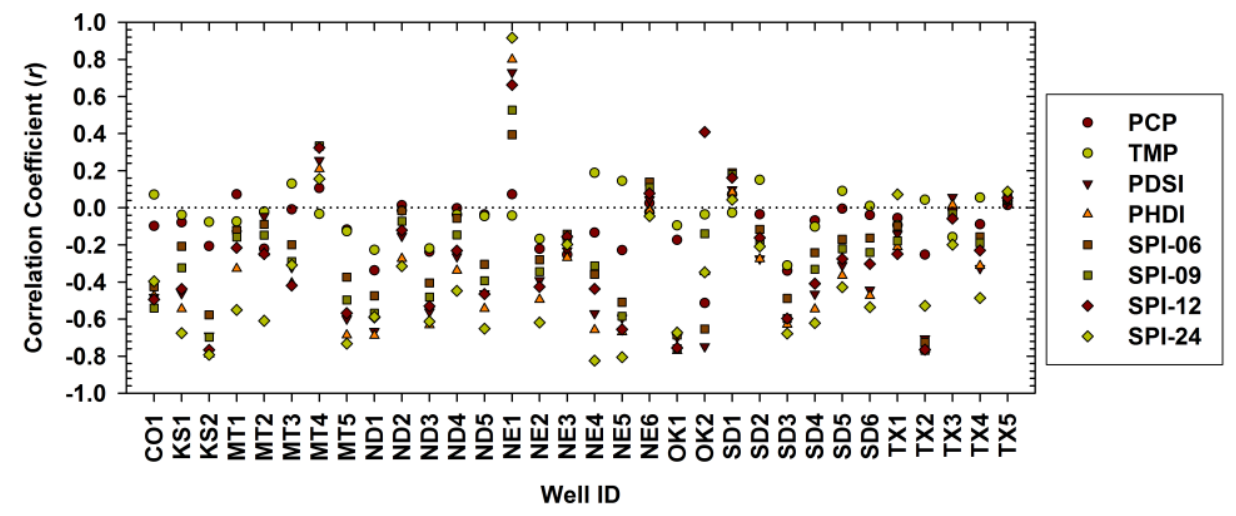

Figure 2. The Pearson correlation coefficient, $r$, between groundwater level, $b$, and drought index.

Based on the results of the overall correlation between $b$ values and drought indices, the SPI-24 index is a viable candidate for understanding groundwater level fluctuations during a discernible drought. Even though an index like PDSI is extensively used for drought quantification, it does not effectively capture hydrological impacts such as groundwater deficit. The PDSI is an effective measurement index of soil moisture conditions. The PHDI, a modified version of PDSI, can capture groundwater deficit. However, the SPI is a simple index, solely based on precipitation records. The SPI quantifies the precipitation deficit for multiple time scales. The SPI with a longer time scale or a moving averaging window such as SPI-24, can capture distinctive wet or dry trends, and connect them to streamflow, reservoirs, and groundwater responses. A study of groundwater level responses to the SPI will be advantageous in groundwater management and monitoring during discernible drought episodes, owing to the fact that precipitation records are widely available. Thus, SPI-24 may be regarded as a proxy measure of groundwater levels.

Table 1 shows the estimated coefficients for the regression models of SPI-24 and $b$, estimated standard error (SE) of coefficients, $t$-test statistic values, and $p$-values for each well. Negative values of $\beta_{1}$ suggest that $b$ reduces with increasing SPI- 24 , as expected. The wells MT4, NE1, SD1, TX1, and TX5 show the positive $\beta_{1}$. Even though TX1 shows a positive $\beta_{1}$, it shows a negative correlation with respect to other indices with SPI-24 (Figure 2). The small $p$-value $(<0.05)$ suggests that the relationship between $b$ and SPI-24 is significant, and $\beta_{1}$ is not null. The observed significant values ( $p$-values) in $t$-tests for coefficient $\beta_{1}$, show that SPI-24 has a significant influence on $b$ (at $\alpha=0.05$ ) for all of the wells, except NE6, OK2, SD1, and TX1. 
Table 1. Results of regression analysis.

\begin{tabular}{|c|c|c|c|c|c|c|c|c|c|c|c|}
\hline Well ID & & Coef. & SE & $\mathrm{T}$ & $\mathbf{P}$ & Well ID & & Coef. & SE & $\mathrm{T}$ & $\mathbf{P}$ \\
\hline \multirow[b]{2}{*}{ CO1 } & $\beta_{0}$ & 6.25 & 0.01 & 602.78 & 0.000 & \multirow[b]{2}{*}{ NE4 } & $\beta_{0}$ & 0.78 & 0.04 & 17.38 & 0.000 \\
\hline & $\beta_{1}$ & -0.04 & 0.01 & -4.89 & 0.000 & & $\beta_{1}$ & -0.25 & 0.03 & -7.28 & 0.000 \\
\hline \multirow{2}{*}{ KS1 } & $\beta_{0}$ & 3.79 & 0.07 & 57.26 & 0.000 & \multirow{2}{*}{ NE5 } & $\beta_{0}$ & 2.44 & 0.03 & 75.56 & 0.000 \\
\hline & $\beta_{1}$ & -0.70 & 0.06 & -11.57 & 0.000 & & $\beta_{1}$ & -0.17 & 0.02 & -9.52 & 0.000 \\
\hline \multirow{2}{*}{ KS2 } & $\beta_{0}$ & 6.35 & 0.02 & 360.74 & 0.000 & \multirow[b]{2}{*}{ NE6 } & $\beta_{0}$ & 14.18 & 0.05 & 258.48 & 0.000 \\
\hline & $\beta_{1}$ & -0.60 & 0.02 & -35.28 & 0.000 & & $\beta_{1}$ & -0.05 & 0.05 & -1.08 & 0.280 \\
\hline \multirow{2}{*}{ MT1 } & $\beta_{0}$ & 48.72 & 0.14 & 347.19 & 0.000 & \multirow{2}{*}{ OK1 } & $\beta_{0}$ & 33.77 & 0.08 & 438.32 & 0.000 \\
\hline & $\beta_{1}$ & -1.28 & 0.14 & -8.88 & 0.000 & & $\beta_{1}$ & -1.76 & 0.08 & -22.91 & 0.000 \\
\hline \multirow{2}{*}{ MT2 } & $\beta_{0}$ & 26.83 & 0.05 & 577.91 & 0.000 & \multirow[b]{2}{*}{ OK2 } & $\beta_{0}$ & 38.07 & 0.09 & 404.35 & 0.000 \\
\hline & $\beta_{1}$ & -0.26 & 0.04 & -5.85 & 0.000 & & $\beta_{1}$ & -0.13 & 0.09 & -1.49 & 0.156 \\
\hline \multirow{2}{*}{ MT3 } & $\beta_{0}$ & 9.40 & 0.01 & 761.55 & 0.000 & \multirow{2}{*}{ SD1 } & $\beta_{0}$ & 12.72 & 0.03 & 403.61 & 0.000 \\
\hline & $\beta_{1}$ & -0.05 & 0.01 & -4.37 & 0.000 & & $\beta_{1}$ & 0.02 & 0.03 & 0.73 & 0.464 \\
\hline \multirow[b]{2}{*}{ MT4 } & $\beta_{0}$ & 42.09 & 0.01 & 3363.45 & 0.000 & \multirow{2}{*}{ SD2 } & $\beta_{0}$ & 12.70 & 0.11 & 120.18 & 0.000 \\
\hline & $\beta_{1}$ & 0.03 & 0.01 & 2.09 & 0.038 & & $\beta_{1}$ & -0.35 & 0.09 & -3.71 & 0.000 \\
\hline \multirow{2}{*}{ MT5 } & $\beta_{0}$ & 13.30 & 0.01 & 1123.18 & 0.000 & \multirow{2}{*}{ SD3 } & $\beta_{0}$ & 2.07 & 0.06 & 36.90 & 0.000 \\
\hline & $\beta_{1}$ & -0.16 & 0.01 & -14.37 & 0.000 & & $\beta_{1}$ & -0.45 & 0.05 & -9.94 & 0.000 \\
\hline \multirow[b]{2}{*}{ ND1 } & $\beta_{0}$ & 1.72 & 0.02 & 83.83 & 0.000 & \multirow{2}{*}{ SD4 } & $\beta_{0}$ & 2.00 & 0.42 & 4.73 & 0.000 \\
\hline & $\beta_{1}$ & -0.35 & 0.02 & -17.33 & 0.000 & & $\beta_{1}$ & -5.21 & 0.40 & -13.00 & 0.000 \\
\hline \multirow{2}{*}{ ND2 } & $\beta_{0}$ & 6.60 & 0.04 & 161.51 & 0.000 & \multirow{2}{*}{ SD5 } & $\beta_{0}$ & 9.09 & 0.18 & 49.28 & 0.000 \\
\hline & $\beta_{1}$ & -0.24 & 0.04 & -6.62 & 0.000 & & $\beta_{1}$ & -1.32 & 0.19 & -7.07 & 0.000 \\
\hline \multirow{2}{*}{ ND3 } & $\beta_{0}$ & 5.64 & 0.02 & 348.93 & 0.000 & \multirow{2}{*}{ SD6 } & $\beta_{0}$ & 9.68 & 0.09 & 110.93 & 0.000 \\
\hline & $\beta_{1}$ & -0.27 & 0.02 & -16.58 & 0.000 & & $\beta_{1}$ & -0.89 & 0.10 & -9.23 & 0.000 \\
\hline \multirow{2}{*}{ ND4 } & $\beta_{0}$ & 7.12 & 0.02 & 378.18 & 0.000 & \multirow{2}{*}{$\mathrm{TX} 1$} & $\beta_{0}$ & 54.16 & 0.14 & 377.00 & 0.000 \\
\hline & $\beta_{1}$ & -0.22 & 0.02 & -11.58 & 0.000 & & $\beta_{1}$ & 0.08 & 0.13 & 0.58 & 0.565 \\
\hline \multirow{2}{*}{ ND5 } & $\beta_{0}$ & 3.10 & 0.02 & 160.01 & 0.000 & \multirow{2}{*}{ TX2 } & $\beta_{0}$ & 7.66 & 0.04 & 196.64 & 0.000 \\
\hline & $\beta_{1}$ & -0.29 & 0.02 & -16.72 & 0.000 & & $\beta_{1}$ & -0.44 & 0.04 & -11.38 & 0.000 \\
\hline \multirow{2}{*}{ NE1 } & $\beta_{0}$ & 31.87 & 0.01 & 4149.44 & 0.000 & & $\beta_{0}$ & 15.21 & 0.03 & 436.75 & 0.000 \\
\hline & $\beta_{1}$ & 0.11 & 0.00 & 21.23 & 0.000 & TX3 & $\beta_{1}$ & -0.09 & 0.03 & -2.76 & 0.006 \\
\hline & $\beta_{0}$ & 1.09 & 0.01 & 78.48 & 0.000 & & $\beta_{0}$ & 22.99 & 0.03 & 886.17 & 0.000 \\
\hline NE2 & $\beta_{1}$ & -0.17 & 0.01 & -13.75 & 0.000 & TX4 & $\beta_{1}$ & -0.15 & 0.02 & -6.59 & 0.000 \\
\hline & $\beta_{0}$ & 1.93 & 0.04 & 45.52 & 0.000 & & $\beta_{0}$ & 24.23 & 0.40 & 60.91 & 0.000 \\
\hline NE3 & $\beta_{1}$ & -0.09 & 0.03 & -2.69 & 0.008 & TX5 & $\beta_{1}$ & 0.94 & 0.40 & 2.35 & 0.019 \\
\hline
\end{tabular}

The variation of $b$ and SPI-24 for the wells MT4, NE1, SD1, TX5, and KS2, is shown in Figure 3. The wells MT4, NE1, SD1, and TX5 displayed positive correlation with drought indices, as opposed to the expected negative $r$. The well KS2 displayed a strong linear negative correlation. From Figure 3, we can see that the $b$ values are not reflecting drought conditions for the wells MT4, NE1, SD1, and TX5. Well MT4 is in an Upper Cretaceous aquifer comprised of mudstone, sandstone, and a basal conglomerate. The depth to the water is approximately $42 \mathrm{~m}$, which implies that responses to precipitation or drought may take considerable time. In addition, the possibility that mudstone units may overlie the aquifer material in which the well is completed, could mean that surface responses to wet and dry periods would be further delayed. Well NE1 is in the High Plains aquifer and the depth to the water level is substantial enough $(\sim 31.5 \mathrm{~m})$ that responses to precipitation may also take considerable time. Thus, the depth of the unsaturated zone could cause a delay in the response to wet and dry conditions. Perhaps the drop in the record's groundwater level is the response to the previous dry period, and the rise in the groundwater level is due to the wet period, over which the water-level record is superimposed. Well SD1 is $55 \mathrm{~m}$ deep and is in the Arikaree Formation. The depth to the water for SD1 is relatively shallow $(\sim 13 \mathrm{~m})$. The well recharge might have been affected by the variation in pumping, in response to wet and dry conditions. Well SD1 was removed from the 
CRN network by the USGS. Well TX5 most likely represents the long-term, continued decline of water levels in the High Plains Aquifer system of Texas, in response to irrigation pumping. The depth to the groundwater has become substantial and the area can be classified as semi-arid to arid, thus, the water level is little affected by precipitation. The well location is probably not close to pumping wells, otherwise a seasonal pumping signal would be expected. The inclusion of wells MT4, NE1, and TX5 in the CRN network, may need further reconsideration, and is beyond the scope of this study. However, wells located in shallow aquifers with no pumping or recharge effects can be used in assessing groundwater responses during drought.
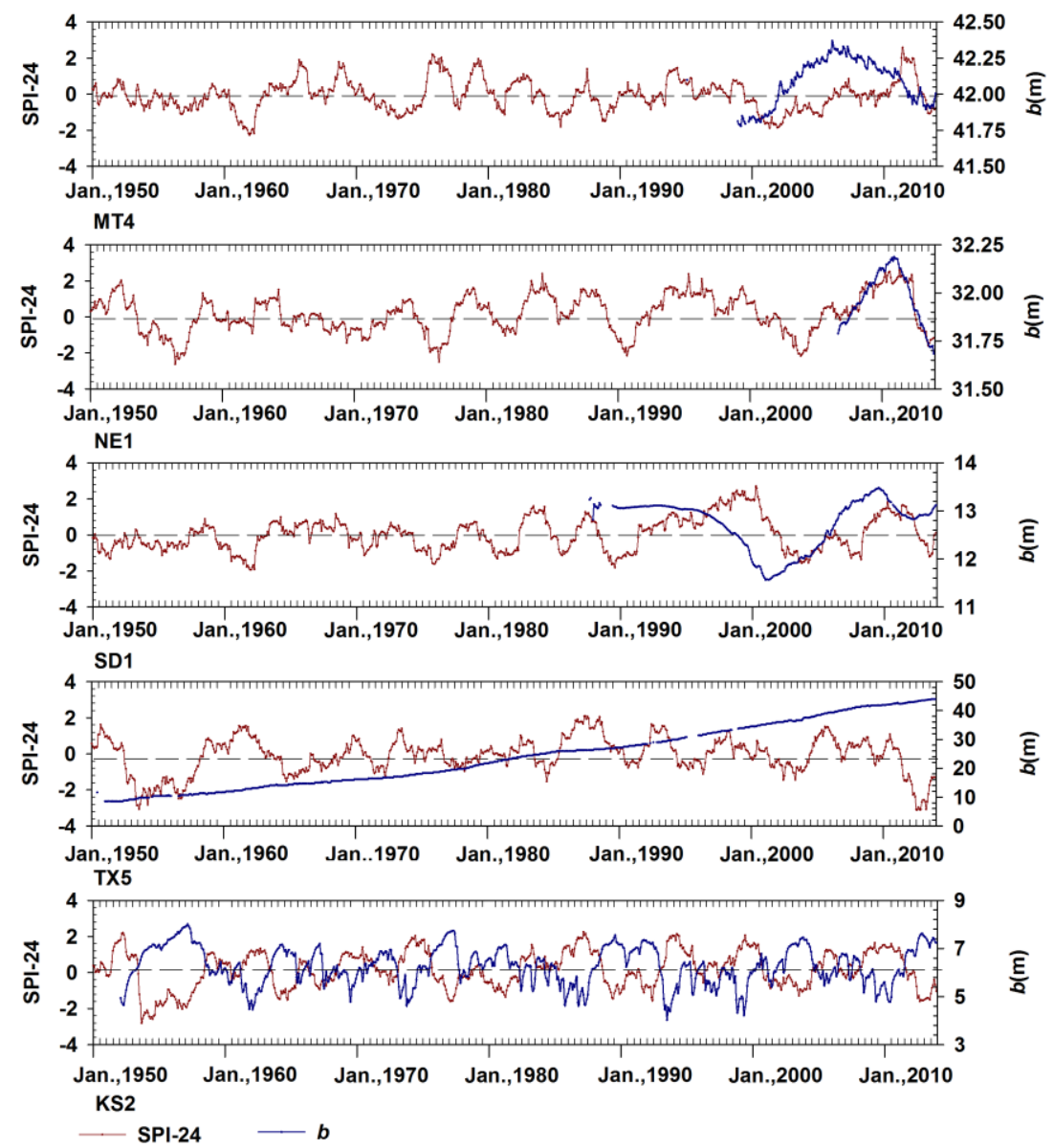

Figure 3. The variation of the 24-month Standardized Precipitation Index (SPI-24) and depth to water level, $b$, for wells MT4, NE1, SD1, and TX5, that displayed positive correlation.

The variation in the groundwater level and its correlation with SPI-24, were further analyzed on a monthly time basis for a select set of wells. The selected wells were KS2, ND1, ND2, ND3, ND4, ND5, NE6, OK1, and TX2. These wells had at least 25 years of reported monthly records. TX5 had more than 25 years of monthly records for each month, but was not used for this part of study because its water level was declining, irrespective of any established drought episodes (Figure 3). The tabulated results in Table 2 include correlation coefficient values $\left(r^{\prime}\right)$ between SPI-24 and $b$ for each month, and average values of depth to the water level, from the land surface, $\mu$. 
Table 2. Correlation coefficients between SPI-24 and $b\left(r^{\prime}\right)$, sample size $(n)$, and average of monthly median values $(\mu)$.

\begin{tabular}{|c|c|c|c|c|c|c|c|c|c|c|c|c|c|}
\hline $\begin{array}{c}\text { ID } \\
\text { (Time Frame) }\end{array}$ & Pr & January & February & March & April & May & June & July & August & September & October & November & December \\
\hline \multirow{3}{*}{$\begin{array}{c}\text { KS2 } \\
(1953-2013)\end{array}$} & $r^{\prime}$ & -0.84 & -0.82 & -0.82 & -0.78 & -0.81 & -0.79 & -0.77 & -0.76 & -0.75 & -0.80 & -0.81 & -0.82 \\
\hline & $n$ & 61 & 60 & 61 & 61 & 61 & 61 & 61 & 61 & 61 & 61 & 61 & 60 \\
\hline & $\mu$ & 6.38 & 6.39 & 6.34 & 6.24 & 6.14 & 6.03 & 6.12 & 6.31 & 6.38 & 6.32 & 6.32 & 6.35 \\
\hline \multirow{3}{*}{$\begin{array}{c}\text { ND1 } \\
(1964-2013)\end{array}$} & $r^{\prime}$ & -0.75 & -0.72 & -0.73 & -0.60 & -0.57 & -0.57 & -0.60 & -0.65 & -0.67 & -0.68 & -0.69 & -0.69 \\
\hline & $n$ & 49 & 44 & 48 & 49 & 46 & 47 & 47 & 47 & 47 & 48 & 48 & 49 \\
\hline & $\mu$ & 1.92 & 1.97 & 1.83 & 1.21 & 1.18 & 1.31 & 1.48 & 1.79 & 1.87 & 1.77 & 1.67 & 1.77 \\
\hline \multirow{3}{*}{$\begin{array}{c}\text { ND2 } \\
(1979-2013)\end{array}$} & $r^{\prime}$ & -0.42 & -0.38 & -0.31 & -0.36 & -0.30 & -0.33 & -0.32 & -0.31 & -0.29 & -0.29 & -0.24 & -0.28 \\
\hline & $n$ & 29 & 28 & 33 & 33 & 35 & 35 & 35 & 35 & 34 & 35 & 35 & 32 \\
\hline & $\mu$ & 6.52 & 6.52 & 6.48 & 6.41 & 6.36 & 6.36 & 6.47 & 6.65 & 6.69 & 6.58 & 6.50 & 6.51 \\
\hline \multirow{3}{*}{$\begin{array}{c}\text { ND3 } \\
(1969-2013)\end{array}$} & $r^{\prime}$ & -0.68 & -0.68 & -0.67 & -0.60 & -0.73 & -0.64 & -0.55 & -0.58 & -0.65 & -0.66 & -0.67 & -0.72 \\
\hline & $n$ & 36 & 37 & 39 & 36 & 32 & 42 & 39 & 41 & 36 & 44 & 40 & 36 \\
\hline & $\mu$ & 5.77 & 5.76 & 5.64 & 5.45 & 5.45 & 5.40 & 5.47 & 5.58 & 5.68 & 5.66 & 5.67 & 5.73 \\
\hline \multirow{3}{*}{$\begin{array}{c}\text { ND4 } \\
(1966-2013)\end{array}$} & $r^{\prime}$ & -0.43 & -0.34 & -0.34 & -0.38 & -0.36 & -0.48 & -0.43 & -0.35 & -0.36 & -0.38 & -0.37 & -0.41 \\
\hline & $n$ & 45 & 45 & 47 & 46 & 46 & 46 & 45 & 46 & 47 & 46 & 47 & 47 \\
\hline & $\mu$ & 7.07 & 7.08 & 7.11 & 7.06 & 7.03 & 7.00 & 7.03 & 7.11 & 7.14 & 7.09 & 7.08 & 7.07 \\
\hline \multirow{3}{*}{$\begin{array}{c}\text { ND5 } \\
(1981-2013)\end{array}$} & $r^{\prime}$ & -0.68 & -0.68 & -0.67 & -0.64 & -0.68 & -0.73 & -0.58 & -0.64 & -0.63 & -0.61 & -0.62 & -0.65 \\
\hline & $n$ & 31 & 29 & 29 & 31 & 33 & 33 & 30 & 31 & 30 & 33 & 32 & 31 \\
\hline & $\mu$ & 2.96 & 3.01 & 3.04 & 3.03 & 3.03 & 2.95 & 2.90 & 2.85 & 2.93 & 2.93 & 2.93 & 2.93 \\
\hline \multirow{3}{*}{$\begin{array}{c}\text { NE6 } \\
(1967-2013)\end{array}$} & $r^{\prime}$ & -0.04 & -0.06 & -0.06 & -0.07 & -0.08 & -0.02 & -0.04 & -0.02 & -0.02 & -0.01 & -0.04 & -0.05 \\
\hline & $n$ & 46 & 46 & 47 & 47 & 47 & 47 & 46 & 46 & 47 & 47 & 47 & 47 \\
\hline & $\mu$ & 14.18 & 14.17 & 14.11 & 14.06 & 14.01 & 13.98 & 14.02 & 14.24 & 14.35 & 14.37 & 14.35 & 14.33 \\
\hline \multirow{3}{*}{$\begin{array}{c}\text { OK1 } \\
(1960-2013)\end{array}$} & $r^{\prime}$ & -0.75 & -0.71 & -0.73 & -0.62 & -0.73 & -0.76 & -0.71 & -0.69 & -0.75 & -0.75 & -0.71 & -0.70 \\
\hline & $n$ & 52 & 52 & 52 & 54 & 52 & 53 & 54 & 52 & 53 & 54 & 53 & 54 \\
\hline & $\mu$ & 33.71 & 33.75 & 33.42 & 32.66 & 32.27 & 32.14 & 32.79 & 33.80 & 34.44 & 34.49 & 34.20 & 34.02 \\
\hline \multirow{3}{*}{$\begin{array}{c}\text { TX2 } \\
\text { (1981-2013) }\end{array}$} & $r^{\prime}$ & -0.52 & -0.54 & -0.50 & -0.48 & -0.59 & -0.62 & -0.53 & -0.52 & -0.55 & -0.62 & -0.59 & -0.55 \\
\hline & $n$ & 28 & 25 & 30 & 28 & 27 & 27 & 29 & 27 & 28 & 28 & 27 & 26 \\
\hline & $\mu$ & 7.44 & 7.44 & 7.56 & 7.56 & 7.59 & 7.37 & 7.40 & 7.59 & 7.69 & 7.74 & 7.59 & 7.48 \\
\hline
\end{tabular}

Pr-Parameters; $r^{\prime}$ —correlation coefficient; $n$ —number of monthly records; $\mu$-average values of monthly median records in meters. 
Figure 4 shows variation in $r^{\prime}$ and $\mu$. The $\mu$ values for well KS2 vary between $6.03 \mathrm{~m}$ in June and $6.39 \mathrm{~m}$ in February. The $r^{\prime}$ values for KS2 vary between -0.84 in January and -0.75 in September. The $\mu$ and $r^{\prime}$ values for the KS2 well are relatively stable, and the groundwater level had a strong linear correlation with SPI-24. The highest differential value for $r^{\prime}$ is observed for ND1, where $r^{\prime}$ values range between -0.75 for the month of January, and -0.57 for the months of May and June. On the other hand, the $\mu$ value varies between $1.97 \mathrm{~m}$ in February and $1.18 \mathrm{~m}$ in May. The highest differential $\mu$ value was observed for the OK1 well, where the highest $\mu$ value was $34.49 \mathrm{~m}$ in October, and the lowest $\mu$ value was $32.14 \mathrm{~m}$ in June. $\mu$ values for ND4 vary between $7.14 \mathrm{~m}$ in September and $7 \mathrm{~m}$ in June, which was the lowest differential $\mu$ value. The $r^{\prime}$ values for NE6 are very low for all of the months, over the entire period. The annual water-level patterns for the wells show water-level rises during the spring to summer months, implying recharge periods, followed by water-level declines, implying the combined effects of discharge to streams, and possible pumping of the wells during the summer to early fall, followed by the recovery of water levels, possibly due to the cessation of stream discharge or pumping. We did not explore any general or specific patterns for the seasonal variability of $r^{\prime}$. The $r^{\prime}$ values are relatively the same throughout the year. This implies that an extended drought influences the groundwater, regardless of the season of the year. Knowing the variation in the groundwater level, and its correlation with drought on a monthly basis, will be helpful in the identification of seasonal groundwater availability and its susceptibility to drought, and can contribute towards better planning and utility of groundwater resources.

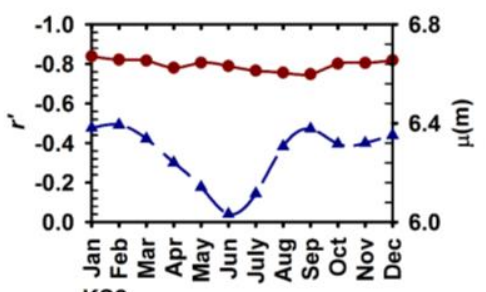

KS2

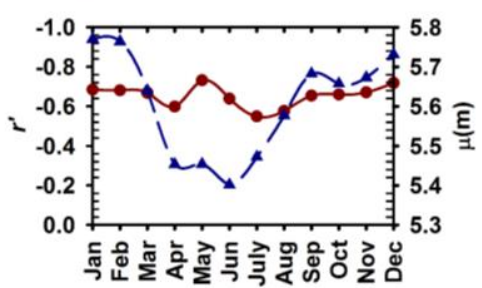

ND3

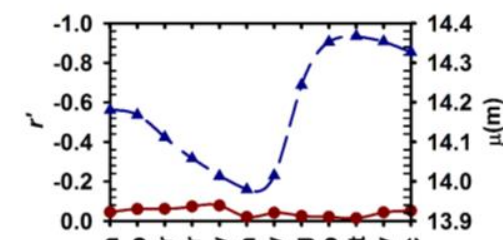

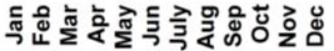
NE6

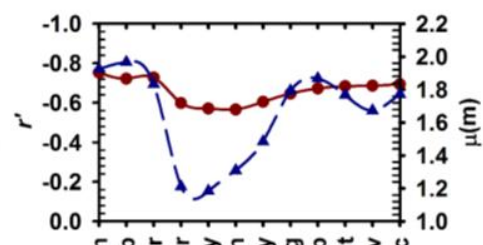

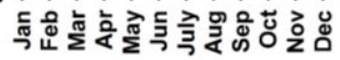
ND1

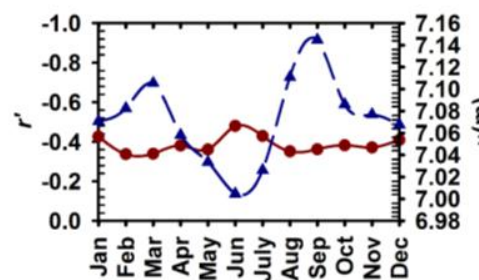
ND4

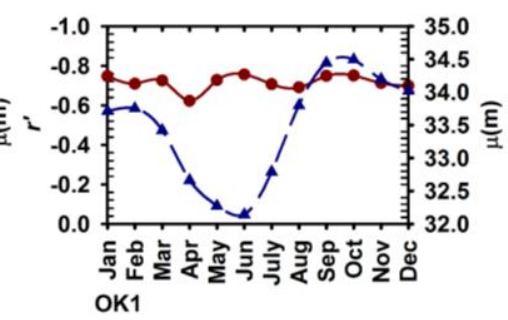

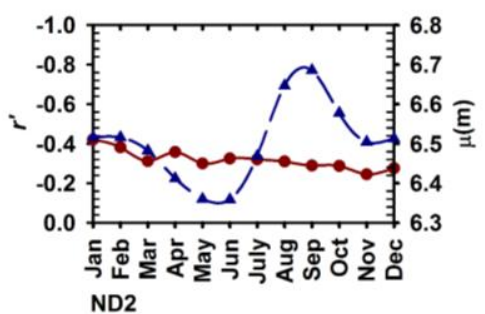

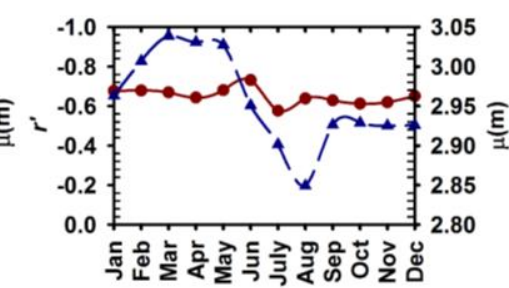

ND5

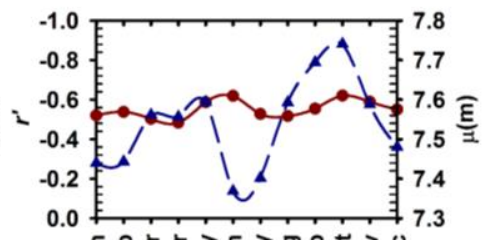

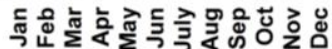
TX2

Figure 4. Monthly variation of $r^{\prime}$ and $\mu$.

To study the effects of drought duration on groundwater decline, seven different events were identified that could satisfy the criteria of SPI- $24 \leq-0.8$ in the area surrounding the well for at least 30 consecutive months. This was also complementary with complete well data spanning a similar time frame of 30 months. Table 3 shows the timeline of drought events (year and month of starting and ending), duration of drought events (number of months under moderate or more severe drought), and available monthly median records of groundwater level records within established drought events. 
Table 3. Pertinent data showing selected drought events and number of groundwater level records.

\begin{tabular}{ccccc}
\hline \multirow{2}{*}{ ID } & \multicolumn{4}{c}{ Drought Events } \\
\cline { 2 - 5 } & Start & End & Duration (Months) & \# Records \\
\hline KS2 & July 1953 & October 1957 & 52 & 52 \\
MT1 & June 2000 & April 2003 & 35 & 35 \\
MT4 & June 2000 & February 2003 & 33 & 32 \\
ND3 & May 1989 & July 1992 & 39 & 39 \\
ND4 & July 1988 & June 1991 & 36 & 36 \\
ND5 & July 1988 & June 1991 & 36 & 35 \\
NE2 & August 1935 & August 1938 & 37 & 30 \\
\hline
\end{tabular}

The variation in the monthly SPI-24 values with temporal groundwater levels is shown in Figure 5 (a-1 to g-1). The $x$-axis shows the year and month. The time frame commences two years before the beginning of the drought, and ends two years after the drought event. As such, we can extract information on lag and recovery times of groundwater levels following a drought. From Figure 5 (a-2 to g-2), we can see the relationship between $b$ and the duration, $d$, of a moderate or more severe drought, that is, a SPI- $24 \leq-0.8$ condition. Wells MT1, MT4, ND3, ND4, and ND5 display a prominent linear relationship with respect to the duration of drought events $(r>0.9)$, when compared to wells KS2 and NE2 (Figure 5: a-2 and g-2). The location and hydrogeological properties of wells KS2 and NE2, such as the relatively shallow water table and proximity to a river, respectively, may be the reason for the relatively low correlation. Table 4 shows the results of: (i) total groundwater decline values during each drought event; (ii) correlation coefficient between depth to the water level and duration, $r$; (iii) fitted linear regression model equations for depth to the water level with duration; and (iv) coefficient of determination, $R^{2}$. The total decline in groundwater was determined from the difference in groundwater levels at the beginning and end of each drought event. The highest $R^{2}$ values were obtained for wells ND4 and ND5, which indicated that $97 \%$ of the variation in the groundwater level may be attributed to the duration of moderate or more severe drought, that is, SPI- $24 \leq-0.8$ conditions. Well NE2 displayed the lowest $R^{2}$ value, of $39 \%$. The water levels for wells KS2 and NE2 started to recover a few months ahead of the end of the associated drought event, thus displaying a relatively low linear correlation value (Figure 5).

The depth to the water level increased or continued to remain high, even after the end of a drought event for wells MT1 and MT4, which could be due to aquifer characteristics such as depth to the water. Wells MT1 and MT4 have relatively large depths to the water, and slow responses to dry and wet conditions. The consequent drought pattern following the defined drought event, may also be the reason for this type of anomaly. Wells MT4 and ND3 show a lag in the response to a drought event. In general, we can surmise that the groundwater decline was linear during established drought events defined as moderate to more severe, that is, those in which the SPI-24 $\leq-0.8$. However, there was variation in groundwater responses before the onset and offset of drought events.

Drought impacts all water dependent sectors, and causes vast economic losses and environmental issues. Hays et al. [44] emphasizes that an impact assessment is vitally important for decision making, responding, and understanding vulnerabilities of drought. Above ground hydrological responses to drought using stream flow data is a vastly studied area compared to studies of influences of drought on groundwater resources. This study investigated the possibility of utilizing drought indices for exploring groundwater level responses to drought. It should also be recognized that inherent challenges also face the establishment of an uncontested parametric relationship between drought indices and groundwater dynamics due to the complex nature of aquifers, such as varying depth, properties of the aquifer and recharge area, and possible anthropogenic influences. 

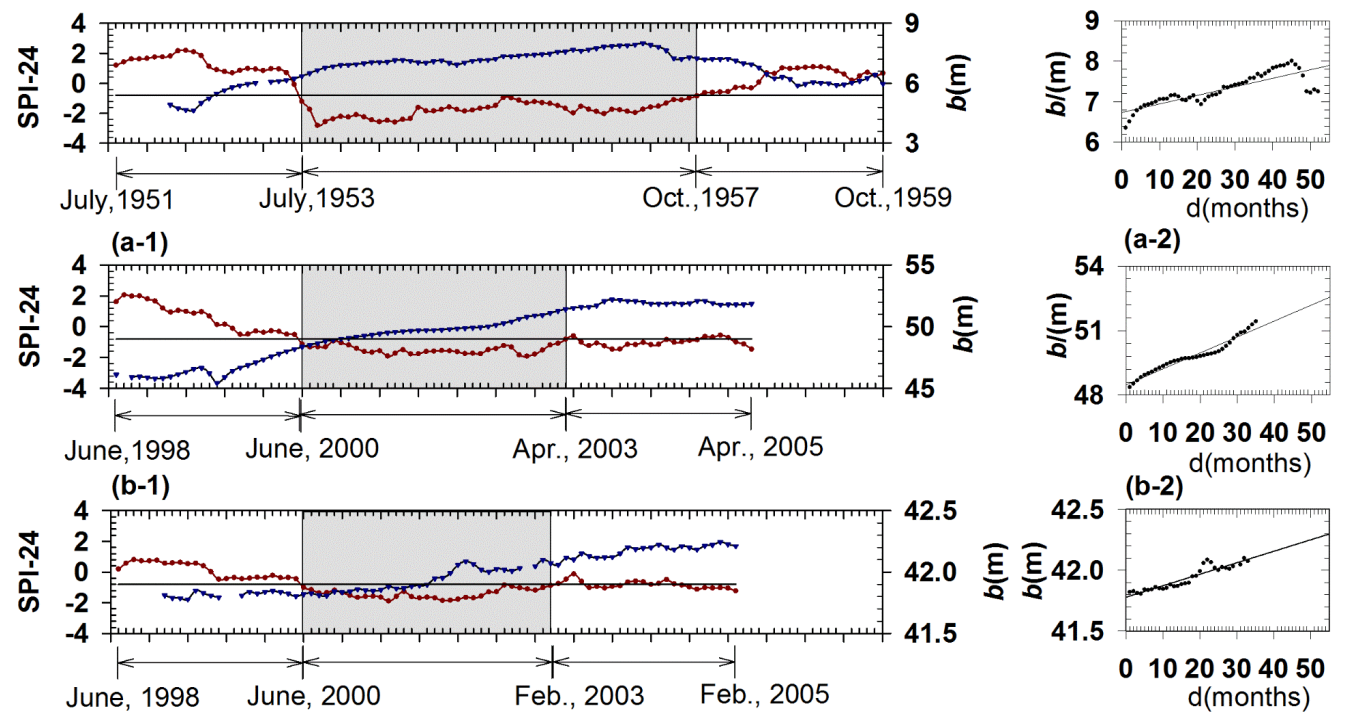

42.5

(b-2) $\mathrm{d}$ (months)

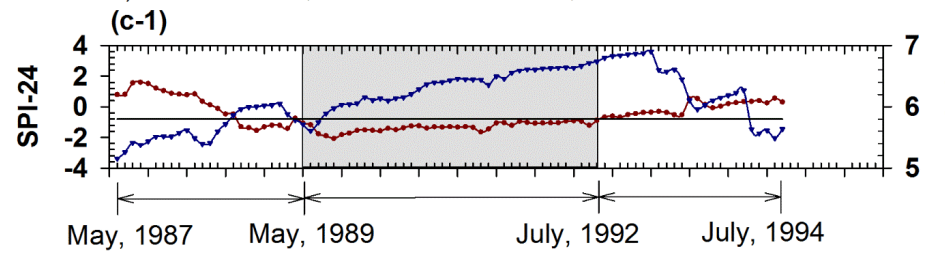

41.5

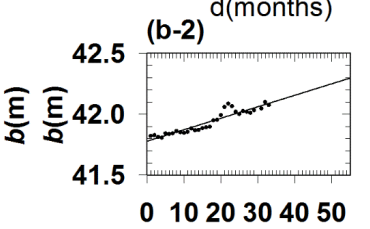

d(months)
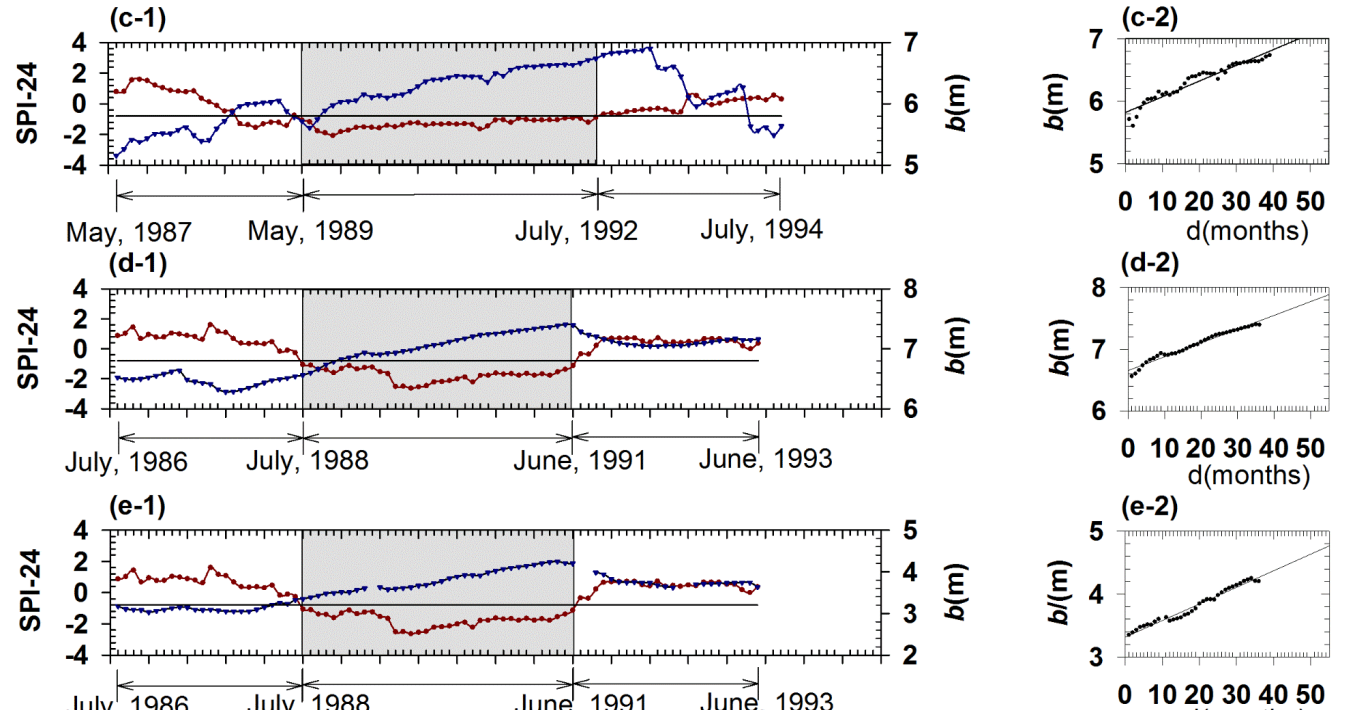

$(\mathrm{e}-2)$
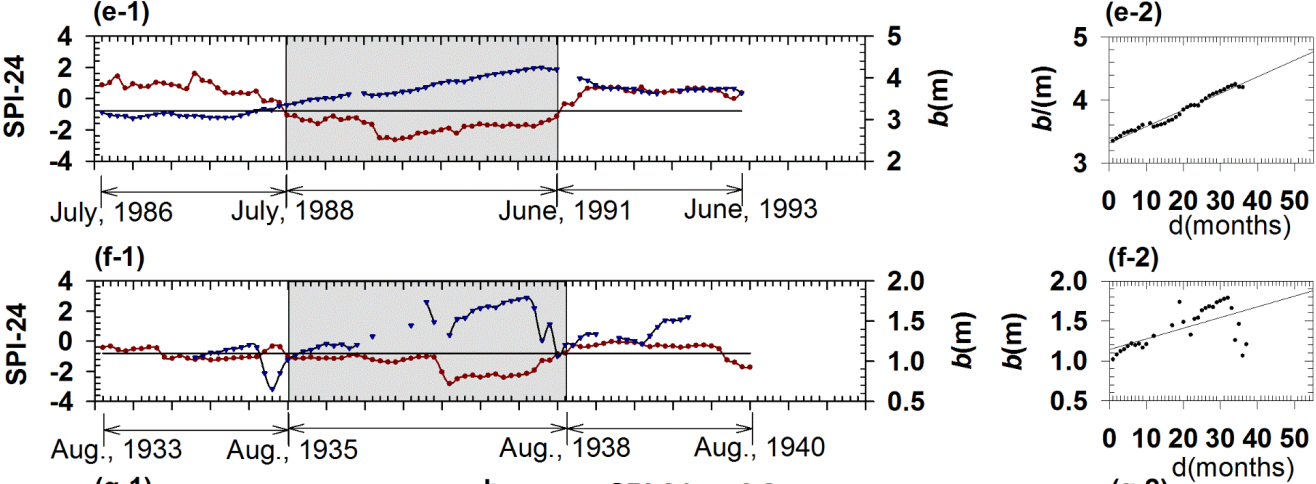

(f-2)

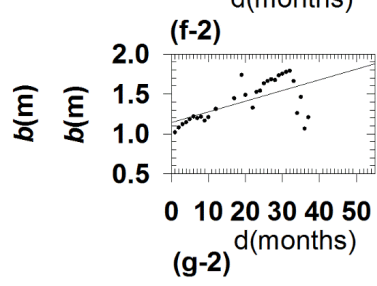

Figure 5. The variation of $b$ with SPI-24 and duration (d) of selected drought events for (a) KS2; (b) MT1; (c) MT4; (d) ND3; (e) ND4; (f) ND5; and (g) NE2.

Table 4. The relationship between $b$ and duration $(d)$ of drought events.

\begin{tabular}{|c|c|c|c|c|c|c|}
\hline \multirow{2}{*}{ ID } & \multicolumn{2}{|c|}{ Time Frame } & \multirow{2}{*}{$\begin{array}{l}\text { Total Drop } \\
\text { (m) }\end{array}$} & \multirow{2}{*}{$r$} & \multirow{2}{*}{$\begin{array}{l}\text { Regression } \\
\text { Model }\end{array}$} & \multirow{2}{*}{$R^{2}(\%)$} \\
\hline & Start & End & & & & \\
\hline KS2 & July 1953 & October 1957 & 0.90 & 0.831 & $b=0.021 d+6.734$ & 69.1 \\
\hline MT1 & June 2000 & April 2003 & 3.05 & 0.976 & $b=0.074 d+48.478$ & 95.3 \\
\hline MT4 & June 2000 & February 2003 & 0.25 & 0.933 & $b=0.009 d+41.779$ & 87.1 \\
\hline ND3 & May 1989 & July 1992 & 1.02 & 0.962 & $b=0.025 d+5.825$ & 92.5 \\
\hline ND4 & July 1988 & June 1991 & 0.84 & 0.986 & $b=0.022 d+6.653$ & 97.3 \\
\hline ND5 & July 1988 & June 1991 & 0.85 & 0.987 & $b=0.026 d+3.318$ & 97.4 \\
\hline NE2 & August 1935 & August 1938 & 0.19 & 0.625 & $b=0.013 d+1.143$ & 39.0 \\
\hline
\end{tabular}




\section{Summary and Conclusions}

This study explored the relationship between groundwater levels and drought indices for wells located in the Great Plains States of the United States. The groundwater level data from USGS CRN wells with minimum anthropogenic disturbances were used. A total of 32 wells were selected for the study. The correlation matrix of the drought indices and depth to groundwater levels (monthly median values) was calculated, and used to identify which reliable drought indices were most valuable for monitoring groundwater responses to drought. It should be noted that the drought indices used in this study were derived from NOAA's NCDC for each climatic division where a well was located. The groundwater observation wells may not represent the groundwater in the larger climatic divisions. It would be more appropriate to consider indices with areal coverage of the recharge area of each well, although this would be impractical for the rapid, simple approach discussed here. Regardless, from this study we found that drought indices were fairly reflective of groundwater responses to drought. The PHDI and SPI-24 indices superseded other indices used in this study and displayed a higher correlation with the groundwater level. Li and Rodell [26] also reported that SPI-24 is a promising drought index in studying groundwater responses to drought. The regression models were developed to examine the relationship between SPI-24 and $b$. The observed significant values ( $p$-values) from $t$-tests show that SPI-24 has a significant influence on $b$ (at $\alpha=0.05$ ), for most of the wells.

The seasonal variability of groundwater levels, and the correlation of groundwater levels with SPI-24, were also studied for selected wells that had adequate data. The correlation with average values of monthly median depths to the water level remained relatively the same throughout the year. The fluctuations in groundwater levels for specific drought events were also examined. Drought events, for this purpose, were defined by a SPI-24 threshold of less than or equal to -0.8 , a category used for moderate or more severe drought. There were seven drought episodes identified, using at least 30 months of groundwater level records. During each defined drought event, the duration of the event was found to have a significant influence on the response of groundwater levels to drought, displaying a prominent linear relationship to groundwater decline. A set of regression equations was developed to establish the relationship between drought duration and the depth to the water level from the land surface, for the selected seven drought events. Based on the $R^{2}$ values, for four wells (MT1, ND3, ND4, and ND5), more than $92 \%$ of the variation in groundwater level can be explained by the drought duration. Decline and recovery times were also discernible for groundwater levels for the defined drought episodes, with respect to each well location. For example, wells MT4 and ND3 had a lag time from the start of a drought event, to when the groundwater level decline was perceptible, whereas wells KS2 and NE4 began to recover prior to the end of the drought event, as represented by SPI-24. A better understanding of the lag and recovery could be gained by conducting an analysis using different indices, such as SPI-6, -9, -12, -24, and PDSI, and a Z-index, and incorporating different lengths of lags.

Observation of groundwater level fluctuations is essential for groundwater monitoring and management. There have been few studies conducted on utilizing other monitoring well networks to study the ground water fluctuation, such as the USGS CRN well network. Kansas has established an Index Well Program that is maintained for examining the response of groundwater to a variety of factors, including climatic and pumping variations. There is a lack of in situ observations in many states due to practical limitations of the establishment and maintenance of observation well networks. Alternatively, establishing a relationship between groundwater and meteorological drought indicators, as accomplished in this study, will be useful in groundwater monitoring and management. Such a study could enable managers to have an estimated groundwater level during drought, based on well-established and readily available drought indices from the widely used source, NOAA NCDC. In addition, the current understanding of the interaction between drought and groundwater is limited. A study like this can be helpful for understanding the response of groundwater levels to various characteristics of drought, such as intensity and duration. However, the relationship between drought and groundwater levels may be region- specific and thus needs to be studied for each region of interest. 
A study using group of wells in an area of an aquifer with relatively similar hydrogeologic properties can help scientists to understand the influences of drought on groundwater.

Acknowledgments: The authors would like to acknowledge: (i) North Dakota Water Recourses Research Institute (ND WRRI) Fellowship Program; and (ii) North Dakota State University Graduate School Doctoral Dissertation Fellowship Award for the financial support of this study.

Author Contributions: Navaratnam Leelaruban, G. Padmanabhan, and Peter Oduor conceived the main idea. Navaratnam Leelaruban performed data collection, construction of data base, and analysis of the data. All three authors jointly wrote the paper.

Conflicts of Interest: The authors declare no conflict of interest.

\section{Appendix}

Table A1. Geographical location of USGS CRN wells used in this study.

\begin{tabular}{|c|c|c|c|c|c|c|}
\hline ID & USGS SITEID & DECLAT & DECLON & STATE & CLIM. DIVISION & COUNTY \\
\hline $\mathrm{CO} 1$ & 382323104200701 & 38.390 & -104.336 & $\mathrm{CO}$ & ARKANSAS DRAINAGE BASIN & Pueblo \\
\hline KS1 & 381119098435301 & 38.189 & -98.732 & KS & SOUTH CENTRAL & Stafford \\
\hline KS2 & 390006095132301 & 39.002 & -95.223 & KS & EAST CENTRAL & Douglas \\
\hline MT1 & 450524112380701 & 45.090 & -112.636 & MT & SOUTHWESTERN & Beaverhead \\
\hline MT2 & 462641110561701 & 46.445 & -110.939 & MT & CENTRAL & Meagher \\
\hline MT3 & 470709106061401 & 47.119 & -106.104 & MT & NORTHEASTERN & Garfield \\
\hline MT4 & 472203111112602 & 47.368 & -111.191 & MT & CENTRAL & Cascade \\
\hline MT5 & 480034105195401 & 48.009 & -105.332 & MT & NORTHEASTERN & McCone \\
\hline ND1 & 462633097163402 & 46.442 & -97.276 & ND & SOUTHEAST & Richland \\
\hline ND2 & 463417099271002 & 46.571 & -99.453 & ND & SOUTHEAST & Logan \\
\hline ND3 & 465755102410701 & 46.965 & -102.686 & ND & SOUTHWEST & Stark \\
\hline ND4 & 475646097372201 & 47.946 & -97.622 & ND & NORTHEAST & GrandForks \\
\hline ND5 & 482908099134601 & 48.486 & -99.230 & ND & NORTHEAST & Towner \\
\hline NE1 & 413130100531202 & 41.525 & -100.888 & $\mathrm{NE}$ & NORTH CENTRAL & McPherson \\
\hline NE2 & 414607102263301 & 41.769 & -102.443 & $\mathrm{NE}$ & PANHANDLE & Garden \\
\hline NE3 & 420204101200502 & 42.034 & -101.335 & $\mathrm{NE}$ & NORTH CENTRAL & Hooker \\
\hline NE4 & 422802097031601 & 42.467 & -97.055 & NE & NORTHEAST & Cedar \\
\hline NE5 & 422849099521503 & 42.480 & -99.871 & $\mathrm{NE}$ & NORTH CENTRAL & Brown \\
\hline NE6 & 423148098300601 & 42.530 & -98.502 & $\mathrm{NE}$ & NORTH CENTRAL & Holt \\
\hline OK1 & 343457096404501 & 34.583 & -96.679 & OK & SOUTH CENTRAL & Pontotoc \\
\hline OK2 & 361739099323301 & 36.294 & -99.543 & OK & NORTH CENTRAL & Woodward \\
\hline SD1 & 430027102311801 & 43.007 & -102.522 & SD & SOUTHWEST & Shannon \\
\hline SD2 & 430027102311806 & 43.007 & -102.522 & SD & SOUTHWEST & Shannon \\
\hline SD3 & 434330096434801 & 43.725 & -96.730 & SD & SOUTHEAST & Minnehaha \\
\hline SD4 & 441759103261202 & 44.300 & -103.437 & SD & BLACK HILLS & Meade \\
\hline SD5 & 442254098174501 & 44.382 & -98.296 & SD & EAST CENTRAL & Beadle \\
\hline SD6 & 451848096363501 & 45.313 & -96.610 & SD & NORTHEAST & Grant \\
\hline TX1 & 293202099063501 & 29.534 & -99.110 & $\mathrm{TX}$ & SOUTH CENTRAL & Medina \\
\hline TX2 & 295443097554201 & 29.912 & -97.929 & $\mathrm{TX}$ & SOUTH CENTRAL & Hays \\
\hline TX3 & 302948095422501 & 30.499 & -95.711 & $\mathrm{TX}$ & EAST TEXAS & Montgomery \\
\hline TX4 & 303143095334801 & 30.528 & -95.564 & $\mathrm{TX}$ & EAST TEXAS & Walker \\
\hline TX5 & 341010102240801 & 34.170 & -102.403 & $\mathrm{TX}$ & HIGH PLAINS & Lamb \\
\hline
\end{tabular}

SITEID—Site Identity, DECLAT—Latitude in decimal degrees, DECLON—Longitude in decimal degrees, CLIM. Division—Climatic Division.

Table A2. Descriptive statistics of groundwater level data used in this study.

\begin{tabular}{|c|c|c|c|c|c|c|c|}
\hline \multirow{2}{*}{ State } & \multirow{2}{*}{ Well ID } & \multicolumn{2}{|c|}{ Time Span } & \multirow{2}{*}{$\begin{array}{l}\text { Records } \\
\text { (Months) }\end{array}$} & \multicolumn{3}{|c|}{$\begin{array}{c}\text { Median Depth to Water } \\
\text { Level-Below Land Surface/(m) }\end{array}$} \\
\hline & & \multicolumn{2}{|c|}{ (Year/Month) (Year/Month) } & & Avg. & Max & Min \\
\hline $\mathrm{CO}$ & $\mathrm{CO} 1$ & $2003 / 03$ & $2013 / 12$ & 130 & 6.27 & 6.53 & 6.04 \\
\hline \multirow[t]{2}{*}{ KS } & KS1 & $2000 / 04$ & $2013 / 12$ & 161 & 3.45 & 5.17 & 1.14 \\
\hline & KS2 & $1952 / 02$ & $2013 / 12$ & 741 & 6.26 & 8.01 & 4.02 \\
\hline
\end{tabular}


Table A2. Cont.

\begin{tabular}{|c|c|c|c|c|c|c|c|}
\hline \multirow{2}{*}{ State } & \multirow{2}{*}{ Well ID } & \multicolumn{2}{|c|}{ Time Span } & \multirow{2}{*}{$\begin{array}{l}\text { Records } \\
\text { (Months) }\end{array}$} & \multicolumn{3}{|c|}{$\begin{array}{c}\text { Median Depth to Water } \\
\text { Level-Below Land Surface/(m) }\end{array}$} \\
\hline & & \multicolumn{2}{|c|}{$\begin{array}{l}\text { Begin End } \\
\text { (Year/Month) (Year/Month) }\end{array}$} & & Avg. & $\operatorname{Max}$ & Min \\
\hline \multirow[t]{5}{*}{ MT } & MT1 & 1998/08 & $2013 / 12$ & 183 & 49.28 & 52.19 & 44.33 \\
\hline & MT2 & $2009 / 01$ & $2013 / 12$ & 60 & 26.72 & 27.44 & 25.95 \\
\hline & MT3 & $1998 / 04$ & $2013 / 12$ & 183 & 9.38 & 9.78 & 8.98 \\
\hline & MT4 & $1998 / 12$ & $2013 / 12$ & 178 & 42.09 & 42.37 & 41.78 \\
\hline & MT5 & $1998 / 10$ & $2013 / 12$ & 180 & 13.22 & 13.39 & 12.42 \\
\hline \multirow[t]{5}{*}{ ND } & ND1 & $1963 / 09$ & $2013 / 12$ & 573 & 1.65 & 2.76 & 0.42 \\
\hline & ND2 & $1978 / 11$ & $2013 / 12$ & 400 & 6.50 & 8.41 & 4.47 \\
\hline & ND3 & $1968 / 12$ & $2013 / 12$ & 459 & 5.61 & 6.90 & 4.28 \\
\hline & ND4 & $1968 / 06$ & $2013 / 12$ & 538 & 7.05 & 8.07 & 5.93 \\
\hline & ND5 & $1980 / 06$ & $2013 / 12$ & 380 & 2.96 & 4.25 & 2.25 \\
\hline \multirow[t]{6}{*}{$\mathrm{NE}$} & NE1 & $2006 / 09$ & $2013 / 12$ & 88 & 31.97 & 32.19 & 31.68 \\
\hline & NE2 & $1934 / 08$ & $2013 / 12$ & 307 & 1.11 & 1.88 & 0.28 \\
\hline & NE3 & $1998 / 12$ & $2013 / 12$ & 180 & 1.89 & 3.51 & 0.98 \\
\hline & NE4 & $2011 / 10$ & $2013 / 12$ & 27 & 0.96 & 1.50 & 0.47 \\
\hline & NE5 & $2009 / 10$ & $2013 / 12$ & 51 & 2.26 & 2.84 & 1.78 \\
\hline & NE6 & $1966 / 10$ & $2013 / 12$ & 563 & 14.16 & 16.37 & 10.81 \\
\hline \multirow[t]{2}{*}{ OK } & OK1 & $1959 / 11$ & 201312 & 637 & 33.48 & 38.96 & 22.98 \\
\hline & $\mathrm{OK} 2$ & $2012 / 07$ & 201312 & 18 & 38.19 & 38.53 & 37.83 \\
\hline \multirow[t]{6}{*}{ SD } & SD1 & $1989 / 06$ & $2013 / 12$ & 294 & 12.73 & 13.48 & 11.57 \\
\hline & SD2 & $1987 / 10$ & $2013 / 12$ & 305 & 12.59 & 19.63 & 10.52 \\
\hline & SD3 & $2004 / 02$ & $2013 / 12$ & 118 & 1.71 & 3.04 & 0.52 \\
\hline & SD4 & $1990 / 11$ & $2013 / 12$ & 271 & 0.31 & 16.66 & -13.22 \\
\hline & SD5 & $1979 / 06$ & $2013 / 12$ & 225 & 8.58 & 13.75 & 3.03 \\
\hline & SD6 & $1979 / 10$ & $2013 / 12$ & 213 & 9.58 & 11.70 & 5.86 \\
\hline \multirow[t]{5}{*}{$\mathrm{TX}$} & TX1 & $2002 / 03$ & $2013 / 12$ & 67 & 54.19 & 58.21 & 51.42 \\
\hline & $\mathrm{TX} 2$ & $1980 / 07$ & $2013 / 10$ & 336 & 7.55 & 8.64 & 4.56 \\
\hline & TX3 & $1952 / 11$ & $2013 / 12$ & 187 & 15.20 & 17.78 & 13.91 \\
\hline & $\mathrm{TX} 4$ & $1989 / 12$ & $2013 / 12$ & 142 & 22.96 & 23.68 & 21.71 \\
\hline & TX5 & $1951 / 01$ & $2013 / 12$ & 725 & 24.15 & 43.92 & 8.53 \\
\hline
\end{tabular}

\section{References}

1. Leelaruban, N.; Padmanabhan, G. Droughts-groundwater relationship in Northern Great Plains Shallow Aquifers. In Proceedings of the World Environmental and Water Resources Congress, Austin, TX, USA, 17-21 May 2015; pp. 510-519. [CrossRef]

2. Wilhite, D.A.; Glantz, M.H. Understanding: The drought phenomenon: The role of definitions. Water Int. 1985, 10, 111-120. [CrossRef]

3. Dracup, J.A.; Lee, K.S.; Paulson, E.G. On the definition of droughts. Water Resour. Res. 1980, 16, $297-302$. [CrossRef]

4. Tallaksen, L.M.; Madsen, H.; Clausen, B. On the definition and modelling of streamflow drought duration and deficit volume. Hydrol. Sci. J. 1997, 42, 15-33. [CrossRef]

5. Mc Kee, T.B.; Doeskin, N.J.; Kleist, J. The relationship of drought frequency and duration to time scales. In Proceedings of the 8th Conference on Applied Climatology, Anaheim, CA, USA, 17-22 January 1993; pp. 179-184.

6. Steinemann, A.C.; Hayes, M.; Cavalcanti, L. Drought indicators and triggers. In Drought and Water Crises: Science, Technology, and Management Issues; Wilhite, D., Ed.; CRC Press: Boca Raton, FL, USA, 2005; pp. 71-92.

7. American Meteorological Society (AMS). AMS Information Statement on Drought. 2013. Available online: https:/ /www.ametsoc.org/ams/index.cfm/about-ams/ams-statements/statements-of-the-amsin-force/drought/ (accessed on 25 September 2016). 
8. Mishra, A.K.; Singh, V.P. A review of drought concepts. J. Hydrol. 2010, 391, 204-216. [CrossRef]

9. Chang, T.J.; Teoh, C.B. Use of the kriging method for studying characteristics of ground-water droughts. Water Resour. Bull. 1995, 31, 1001-1007. [CrossRef]

10. Eltahir, E.A.B.; Yeh, P. On the asymmetric response of aquifer water level to floods and droughts in illinois. Water Resour. Res. 1999, 35, 1199-1217. [CrossRef]

11. Van Loon, A.F. Hydrological drought explained. Wiley Interdiscip. Rev. Water 2015, 2, 359-392. [CrossRef]

12. Chen, Z.H.; Grasby, S.E.; Osadetz, K.G. Predicting average annual groundwater levels from climatic variables: An empirical model. J. Hydrol. 2002, 260, 102-117. [CrossRef]

13. Chen, Z.H.; Grasby, S.E.; Osadetz, K.G. Relation between climate variability and groundwater levels in the upper carbonate aquifer, Southern Manitoba, Canada. J. Hydrol. 2004, 290, 43-62. [CrossRef]

14. Jan, C.D.; Chen, T.H.; Lo, W.C. Effect of rainfall intensity and distribution on groundwater level fluctuations. J. Hydrol. 2007, 332, 348-360. [CrossRef]

15. Panda, D.K.; Mishra, A.; Jena, S.K.; James, B.K.; Kumar, A. The influence of drought and anthropogenic effects on groundwater levels in Orissa, India. J. Hydrol. 2007, 343, 140-153. [CrossRef]

16. Tirogo, J.; Jost, A.; Biaou, A.; Valdes-Lao, D.; Koussoube, Y.; Ribstein, P. Climate variability and groundwater response: A case study in Burkina Faso (West Africa). Water 2016, 8, 171. [CrossRef]

17. Mall, R.K.; Gupta, A.; Singh, R.; Singh, R.S.; Rathore, L.S. Water resources and climate change: An Indian perspective. Curr. Sci. 2006, 90, 1610-1626.

18. Haslinger, K.; Koffler, D.; Schoener, W.; Laaha, G. Exploring the link between meteorological drought and streamflow: Effects of climate-catchment interaction. Water Resour. Res. 2014, 50, 2468-2487. [CrossRef]

19. Vasiliades, L.; Loukas, A. Hydrological response to meteorological drought using the palmer drought indices in Thessaly, Greece. Desalination 2009, 237, 3-21. [CrossRef]

20. Vicente-Serrano, S.M.; Begueria, S.; Lorenzo-Lacruz, J.; Julio Camarero, J.; Lopez-Moreno, J.I.; Azorin-Molina, C.; Revuelto, J.; Moran-Tejeda, E.; Sanchez-Lorenzo, A. Performance of drought indices for ecological, agricultural, and hydrological applications. Earth Interact. 2012, 16, 1-27. [CrossRef]

21. Lorenzo-Lacruz, J.; Vicente-Serrano, S.M.; Lopez-Moreno, J.I.; Begueria, S.; Garcia-Ruiz, J.M.; Cuadrat, J.M. The impact of droughts and water management on various hydrological systems in the headwaters of the Tagus river (central Spain). J. Hydrol. 2010, 386, 13-26. [CrossRef]

22. Shahid, S.; Hazarika, M.K. Groundwater drought in the northwestern districts of Bangladesh. Water Resour. Manag. 2010, 24, 1989-2006. [CrossRef]

23. Fiorillo, F.; Guadagno, F.M. Long karst spring discharge time series and droughts occurrence in Southern Italy. Environ. Earth Sci. 2012, 65, 2273-2283. [CrossRef]

24. Bloomfield, J.P.; Marchant, B.P. Analysis of groundwater drought building on the standardised precipitation index approach. Hydrol. Earth Syst. Sci. 2013, 17, 4769-4787. [CrossRef]

25. Mendicino, G.; Senatore, A.; Versace, P. A groundwater resource index (GRI) for drought monitoring and forecasting in a mediterranean climate. J. Hydrol. 2008, 357, 282-302. [CrossRef]

26. Li, B.; Rodell, M. Evaluation of a model-based groundwater drought indicator in the conterminous U.S. J. Hydrol. 2014, 526, 78-88. [CrossRef]

27. Koster, R.D.; Suarez, M.J.; Ducharne, A.; Stieglitz, M.; Kumar, P. A catchment-based approach to modeling land surface processes in a general circulation model 1. Model structure. J. Geophys. Res. Atmos. 2000, 105, 24809-24822. [CrossRef]

28. Jaranilla-Sanchez, P.A.; Wang, L.; Koike, T. Modeling the hydrologic responses of the Pampanga River basin, Philippines: A quantitative approach for identifying droughts. Water Resour. Res. 2011, 47. [CrossRef]

29. Sawada, Y.; Koike, T.; Jaranilla-Sanchez, P.A. Modeling hydrologic and ecologic responses using a new eco-hydrological model for identification of droughts. Water Resour. Res. 2014, 50, 6214-6235. [CrossRef]

30. Rodell, M.; Velicogna, I.; Famiglietti, J.S. Satellite-based estimates of groundwater depletion in India. Nature 2009, 460, 999-1002. [CrossRef] [PubMed]

31. Famiglietti, J.S.; Lo, M.; Ho, S.L.; Bethune, J.; Anderson, K.J.; Syed, T.H.; Swenson, S.C.; de Linage, C.R.; Rodell, M. Satellites measure recent rates of groundwater depletion in California's central valley. Geophys. Res. Lett. 2011, 38, L03403. [CrossRef]

32. Voss, K.A.; Famiglietti, J.S.; Lo, M.; de Linage, C.; Rodell, M.; Swenson, S.C. Groundwater depletion in the middle east from grace with implications for transboundary water management in the Tigris-Euphrates-Western Iran region. Water Resour. Res. 2013, 49, 904-914. [CrossRef] [PubMed] 
33. Castle, S.L.; Thomas, B.F.; Reager, J.T.; Rodell, M.; Swenson, S.C.; Famiglietti, J.S. Groundwater depletion during drought threatens future water security of the Colorado River basin. Geophys. Res. Lett. 2014, 41, 5904-5911. [CrossRef] [PubMed]

34. Whittemore, D.O.; Butler, J.J.; Wilson, B.B. Assessing the major drivers of water-level declines: New insights into the future of heavily stressed aquifers. Hydrol. Sci. J. 2016, 61, 134-145. [CrossRef]

35. Cunningham, W.L.; Geiger, L.H.; Karavitis, G.A. U.S. Geological Survey Ground-Water Climate Response Network. U.S. Geological Survey Fact Sheet 2007-3003; 2007; 4p. Available online: http:/ / pubs.usgs.gov/ fs /2007/3003/ (accessed on 25 September 2016).

36. Palmer, W.C. Meteorological Drought; Research Paper No. 45; U.S. Department of Commerce, Weather Bureau: Washington, DC, USA, 1965; p. 58.

37. Karl, T.R. The sensitivity of the palmer drought severity index and palmer z-index to their calibration coefficients including potential evapotranspiration. J. Clim. Appl. Meteorol. 1986, 25, 77-86. [CrossRef]

38. Mc Kee, T.B.; Doeskin, N.J.; Kleist, J. Drought Monitoring with Multiple Time Scales. In Proceedings of the 9th Conference on Applied Climatology, Dallas, TX, USA, 15-20 January 1995; pp. 233-236.

39. Fenimore, C.; Arndt, D.; Gleason, K.; Heim, R.R., Jr. Transitioning from the traditional divisional dataset to the Global Historical Climatology Network-Daily gridded divisional dataset. In Proceedings of the 23rd Conference on Climate Variability and Change, Seattle, WA, USA, 22-27 January 2011; Paper Number 6B.5. Available online: https://www.ncdc.noaa.gov/monitoring-references/docs/GrDD-Transition.pdf (accessed on 25 September 2016).

40. Vose, R.S.; Applequist, S.; Squires, M.; Durre, I.; Menne, M.J.; Williams, C.N., Jr.; Fenimore, C.; Gleason, K.; Arndt, D. Improved historical temperature and precipitation time series for U.S. climate divisions. J. Appl. Meteorol. Climatol. 2014, 53, 1232-1251. [CrossRef]

41. Svoboda, M.; Hayes, M.; Wood, D. Standardized Precipitation Index User Guide; Technical Report WMO-No. 1090; World Meteorological Organization: Geneva, Switzerland, 2012; Available online: http:/ /www.wamis. org/agm/pubs/SPI/WMO_1090_EN.pdf (accessed on 25 September 2016).

42. Guttman, N.B.; Quayle, R.G. A historical perspective of U.S. climate divisions. Bull. Am. Meteorol. Soc. 1996, 77, 293-303. [CrossRef]

43. Karl, T.; Koss, W.J. Regional and National Monthly, Seasonal, and Annual Temperature Weighted by Area, 1895-1983; Technical Report; Volume 4, Issue 3 of Historical Climatology Series; National Climatic Data Center: Asheville, NC, USA, 1984; 38p.

44. Hayes, M.; Svoboda, M.; Wall, N.; Widhalm, M. The lincoln declaration on drought indices. Bull. Am. Meteorol. Soc. 2011, 92, 485-488. [CrossRef]

(C) 2017 by the authors; licensee MDPI, Basel, Switzerland. This article is an open access article distributed under the terms and conditions of the Creative Commons Attribution (CC BY) license (http:/ / creativecommons.org/licenses/by/4.0/). 